\title{
Nurses' responsibilities in the aerospace environment
}

\author{
Atribuições do enfermeiro no ambiente aeroespacial \\ Atribuciones del enfermero en el medio ambiente aeroespacial
}

Shara Bianca De Pin Raduenz' ORCID: 0000-0002-4384-6175

José Luís Guedes dos Santos' ORCID: 0000-0003-3186-8286

Daniele Dalcanal Lazzari' ORCID: 0000-0003-1788-866X

Eliane Regina Pereira do Nascimento' ORCID: 0000-0003-2215-4222

Keyla Cristiane do Nascimento' ORCID: 0000-0003-4157-2809

André Ricardo Moreira' ORCID: 0000-0002-9888-5120

'Universidade Federal de Santa Catarina. Florianópolis, Santa Catarina, Brazil.

How to cite this article: Raduenz SBDP, Santos JLG, Lazzari DD, Nascimento ERP, Nascimento KC, Moreira AR. Nurses' responsibilities in the aerospace environment. Rev Bras Enferm. 2020;73(4):e20180777. doi: http://dx.doi.org/10.1590/0034-7167-2018-0777

\section{Corresponding author:}

Shara Bianca De Pin Raduenz

E-mail:sharab_02@hotmail.com

EDITOR IN CHIEF: Dulce Aparecida Barbosa ASSOCIATE EDITOR: Alexandre Balsanelli

Submission: 10-16-2018

Approval: 07-16-2019

\begin{abstract}
Objectives: to characterize the nurses who work in the aerospace environment and to identify their most frequent responsibilities during the pre-flight, flight, and post-flight periods. Methods: a quantitative, exploratory-descriptive research, conducted using a survey through Google forms, from January to April of 2018, with 50 nurses from aerospace services in Brazil. Data were analyzed using descriptive statistics. Results: predominance of male participants (64\%), mean age of 37 years, with a mean working time in the aerospace environment of six years, in helicopter $(54 \%)$, and in the southern region (42\%). The main pre-flight, flight, and post-flight activities were, respectively: verification/testing of equipment functionality, nursing care for patients, and replacement of supplies and equipment. Conclusions: In the aerospace environment, nurses' work are primarily organizational and victim care actions, during all phases of the flight.

Descriptors: Nursing Care; Air Ambulances; Aerospace Medicine; Emergency Medical Services; Nurse's Role.
\end{abstract}

\section{RESUMO}

Objetivos: caracterizar os enfermeiros que atuam no ambiente aeroespacial e identificar as atribuições mais frequentes desenvolvidas por eles durante os períodos pré-voo, voo e pósvoo. Métodos: pesquisa exploratório-descritiva, com abordagem quantitativa, desenvolvida por meio de um survey via Google forms", de janeiro a abril de 2018, com 50 enfermeiros de serviços aeroespaciais do Brasil. Os dados foram analisados por meio de estatística descritiva. Resultados: predominaram participantes do sexo masculino (64\%), com idade média de 37 anos, com tempo médio de atuação no ambiente aeroespacial de seis anos, em aeronaves de asa rotativa (54\%) e provenientes da região Sul (42\%). As principais atividades no pré-voo, durante o voo e pós-voo foram, respectivamente: verificação/teste da funcionalidade de equipamentos, assistência de enfermagem aos pacientes e reposição de insumos e equipamentos. Conclusões: na atuação do enfermeiro no ambiente aeroespacial predominam ações organizacionais e de cuidado à vítima durante todas as etapas do voo. Descritores: Cuidados de Enfermagem; Resgate Aéreo; Medicina Aeroespacial; Serviços Médicos de Emergência; Papel do Profissional de Enfermagem.

\section{RESUMEN}

Objetivos: caracterizar a los enfermeros que actúan en el ambiente aeroespacial e identificar las asignaciones más frecuentes desarrolladas por ellos durante los períodos previos a vuelo, vuelo y post-vuelo. Métodos: investigación exploratoria-descriptiva, con abordaje cuantitativo, desarrollada por medio de una encuesta vía Google forms ${ }^{\circ}$, de enero a abril de 2018, con 50 enfermeros de servicios aeroespaciales de Brasil. Los datos se analizaron por medio de estadística descriptiva. Resultados: predominaron participantes del sexo masculino (64\%), con edad media de 37 años, con tiempo promedio de actuación en el ambiente aeroespacial de seis años, en aeronaves de ala rotativa (54\%) y provenientes de la Región Sur (42\%). Las principales actividades en el pre-vuelo, durante el vuelo y post-vuelo fueron, respectivamente: verificación/prueba de la funcionalidad de equipos, asistencia de enfermería a los pacientes y reposición de insumos y equipamientos. Conclusiones: en la actuación del enfermero en el ambiente aeroespacial predominan acciones organizacionales y de cuidado a la víctima durante todas las etapas del vuelo.

Descriptores: Atención de Enfermería; Ambulancias Aéreas; Medicina Aeroespacial; Servicios Médicos de Urgencia; Rol de la Enfermera. 


\section{INTRODUCTION}

Nursing is a profession in constant transformation, which has its history marked by its integration into new locations of action and care scenarios. According to the Resolution of the Federal Nursing Council (COFEN) $n^{\circ} 389 / 201,42$ nursing specialties exist in Brazil, and one of these specialties is Aerospace Nursing ${ }^{(1-3)}$.

The pre-hospital and inter-hospital care, by means of air vehicles in Brazil, is expanding due to the dimension of the territory, geographical distances, and difficulties of urban traffic in large cities. In addition, there is also an increase in the demand for care due to clinical and traumatic emergencies, whose patients require rapid treatment and referral to hospital emergency services ${ }^{(1,3)}$.

The medical transport aircraft service is part of the mobile pre-hospital component of the emergency care services network, provided by the National Emergency Care Policy, in Brazil, in 2003. The medical transport aircraft is classified as a "Type E" ambulance, which can be a rotary-wing aircraft, which is used for both inter-hospital and rescue operations, or a fixed wing aircraft, which performs the first type of operation cited. Both must be equipped with medical equipment approved by the National Civil Aviation Agency (Agência Nacional de Aviação Civil - ANAC) ${ }^{(4)}$.

Nursing practice in the mobile pre- and inter- hospital care in fixed and/or rotary wing aircraft requires previous experience in pre-hospital and hospital contexts, for the development of specific skills and abilities, such as: decision making, teamwork, rapid intervention, and evaluation of patients' clinical conditions $s^{(1,5-7)}$. In addition, the nurse develops activities related to planning, organization, and provision of resources for comprehensive and safe patient care ${ }^{(1,8)}$.

The adequate performance of nurses' activities within the aerospace crew is directly related to the search for continuous professional qualification, for development of excellent care ${ }^{(1,3,7)}$. However, the regulation of nurses' activities in pre- and interhospital care in air vehicles was only endorsed in 2017, by COFEN Resolution No. $0551^{(8)}$, and scientific publication on the subject is still scarce, mainly in Brazil. It is also important to consider that the aerospace context is a psychologically and physiologically stressful work environment for professionals, depending on the conditions under which the care is performed ${ }^{(6-7)}$.

The aerospace environment is a relatively recent work setting, with great potential for expansion, which needs trained nurses to deal with the challenges inherent in this scenario. Thus, it is necessary to deepen the knowledge about the role of the nurse in the aerospace environment, and to identify whether the activities performed are in line with professional legislation. Knowledge of the nurse's role, as a member of the on-board team, can contribute to the qualification of their professional practice and the construction of their professional identity ${ }^{(3)}$.

Based on the exposed position, the guiding question of this study was: What are the most frequent activities performed by nurses in the aerospace environment?

\section{OBJECTIVES}

To characterize the nurses who work in the aerospace environment, and to identify the most frequent actions performed by them during the pre-flight, flight and post-flight periods.

\section{METHODS}

\section{Ethical aspects}

The study met the ethical precepts of human research in Brazil, and was approved by the Research Ethics Committee of the Federal University of Santa Catarina. All the participants accepted to participate in the study, by agreement with a Free and Informed Consent Form online.

\section{Design, place of study and period}

This was a quantitative, exploratory-descriptive research design, implemented by means of an online survey, using Google forms . A virtual questionnaire was chosen, mainly, to increase the access of nurses throughout the national territory. Thus, the study was not restricted to a specific location.

\section{Sample, inclusion and exclusion criteria}

Data collection was performed from January to April of 2018. The study participants were nurses, working in pre-hospital mobile and inter-hospital care, in fixed and/or rotary wing aircraft, in public or private institutions in Brazil.

The lack of information about pre-hospital and inter-hospital services on aircraft in Brazil made it difficult to recruit nurses directly from institutional employers, or to perform a sample calculation to define the participants of the study. For identification and selection of participants, the link to the survey questionnaire was published on these social networks: Facebook ${ }^{\circledR}$, Instagram ${ }^{\circledR}$ and Linkedin ${ }^{\circledast}$. In addition, electronic contact was made with representative professional organizations and with research groups registered in the Directory of Research Groups in Brazil, of the National Council of Scientific and Technological Development, with lines of research related to the subject. From these strategies, a convenience sample of 50 participants was obtained.

As inclusion criterion, we considered: being a nurse in the pre-hospital mobile and inter-hospital care, in fixed-wing and/ or rotating aircraft, during the data collection period. Questionnaires with incomplete information were excluded.

\section{Study Protocol}

An online form was developed for data collection, with two parts: 1) Sociodemographic and professional characteristics data: sex, age, academic formation, complementary education, time since receiving undergraduate degree, region of the country where working, type of institution, type of aircraft, prior training, other employment relationships, income and weekly workload; and 2) Professional practice, consisting of 13 questions related to the pre-flight (eight), in-flight (four), and post-flight (four) responsibilities, established in COFEN Resolution No. 0551/2017(9).

The nurses provided the frequency with which they performed the activity listed in each question, using a Likert scale with five options: never, rarely, sometimes, often, and always. The data collection instrument was completed, voluntarily, by means of electronic contact, in a form linked to an initial message, which contained an 
invitation to participate in the research. Before the data collection, the instrument was tested with two nurse experts in the area, who did not participate in the study. No changes were necessary to the instrument after this pre-test.

\section{Analysis of the results and statistics}

The quantitative data obtained were organized in a spreadsheet and exported to the SPSS software, version 19.0. Descriptive statistics were used for presentation and analysis of the categorical variables, to calculate the frequency, in absolute number and percentage. For continuous variables, the measurements of position (mean, minimum and maximum) and dispersion (standard deviation) were analyzed.

\section{RESULTS}

Among the 50 nurses participating in the research, 32 (64\%) were males, with a mean age of 37 years. The mean time of experience as a nurse was 10 years, with a mean of six years working in the aerospace environment. Most of them worked in the southern region of Brazil (42\%), in services linked to public institutions (68\%), and in rotary wing aircraft (54\%). When entering the service, $39(78 \%)$ of the nurses reported having received prior training. The mean weekly workload was 37 hours. The monthly income of 21 (42\%) of the nurses was between three and five times the minimum wage (Table 1 ).

With regard to academic education, 58\% had specialization in intensive care or emergency nursing; with regard to complementary training, each participant stated a mean participation in two specific training courses for working in urgent care/emergency. The principal courses were Prehospital Trauma Life Support (19.85\%) and Advanced Cardiac Life Support (18.32\%). One participant did not present any complementary courses in the area (Table 2).

The professional activities conducted by nurses are presented according to the stages: pre-flight, during flight, and post-flight (Table 3). Among the 16 activities analyzed, 15 presented a percentage equal to or greater than $60 \%$ for the "always" option. In pre-flight, the most frequent activity by the participants was verification/test of the functionality of equipment ( $n=42 ; 84.0 \%$ ). During the flight, the main activity of nurses was nursing care integral to the patient, providing care for their physical and mental integrity ( $n=42,84.0 \%)$. In the post-flight period, the nurses' performance was the replacement of supplies and equipment used, according to the institutional protocol ( $n=42,84.0 \%)$.
Table 1 - Sociodemographic profile of nurses ( $n=50)$, Florianópolis, Santa Catarina, Brazil, 2018

\begin{tabular}{|c|c|c|c|c|}
\hline Variable & $N(\%)$ & Mean & $\begin{array}{l}\text { Standard } \\
\text { Deviation }\end{array}$ & $\begin{array}{c}\text { Variation } \\
\text { (min-max) }\end{array}$ \\
\hline \multicolumn{5}{|l|}{ Sex } \\
\hline Male & $32(64.0)$ & & & \\
\hline Female & $18(36.0)$ & & & \\
\hline Age (years) & & 37.18 & 6.33 & $25-57$ \\
\hline Time working in aerospace (years) & & 5.90 & 4.93 & $1-23$ \\
\hline Working time as a nurse (years) & & 10.24 & 4.66 & $2-24$ \\
\hline $\begin{array}{l}\text { Region where working } \\
\text { South } \\
\text { Central-West and Federal District } \\
\text { Southeast } \\
\text { Northeast } \\
\text { North }\end{array}$ & $\begin{array}{l}21(42.0) \\
11(22.0) \\
10(20.0) \\
4(8.0) \\
4(8.0)\end{array}$ & & & \\
\hline $\begin{array}{l}\text { Type of institution } \\
\text { Public } \\
\text { Private }\end{array}$ & $\begin{array}{l}34(68.0) \\
16(32.0)\end{array}$ & & & \\
\hline $\begin{array}{l}\text { Type of aircraft } \\
\text { Rotary wing } \\
\text { Both - Fixed and Rotary wing } \\
\text { Fixed wing }\end{array}$ & $\begin{array}{l}27(54.0) \\
12(24.0) \\
11(22.0)\end{array}$ & & & \\
\hline $\begin{array}{l}\text { Remuneration* } \\
\text { Up to } 3 \text { times the minimum wage } \\
\text { Between } 3 \text { to } 5 \text { times the minimum wage } \\
\text { Between } 5 \text { to } 8 \text { times the minimum wage } \\
\text { More than } 8 \text { times the minimum wage }\end{array}$ & $\begin{array}{l}5(10.0) \\
21(42.0) \\
14(28.0) \\
10(20.0)\end{array}$ & & & \\
\hline $\begin{array}{l}\text { Received training for aerospace service } \\
\text { Yes } \\
\text { No }\end{array}$ & $\begin{array}{l}39(78.0) \\
11(22.0)\end{array}$ & & & \\
\hline $\begin{array}{l}\text { Has another employment relationship } \\
\text { Yes } \\
\text { No }\end{array}$ & $\begin{array}{l}39(78.0) \\
11(22.0)\end{array}$ & & & \\
\hline Weekly workload (in hours) & & 36.6 & 9.1 & $8-60$ \\
\hline
\end{tabular}

Note: ${ }^{*}$ Minimum wage in 2018 (Brazil) $=R \$ 954,00$.

Table 2 - Academic and complementary education $(n=50)$, Florianópolis, Santa Catarina, Brazil, 2018

\begin{tabular}{lc}
\hline Variable & $\mathbf{n ( \% )}$ \\
\hline Maximum Education & \\
University undergraduate degree & $4(8.0)$ \\
Specialization in Aerospace Nursing & $7(14.0)$ \\
Specialization in Intensive Care or Urgent Care / Emergency & $29(58.0)$ \\
Specialization in other area of nursing practice & $8(16.0)$ \\
Master's degree & $2(4.0)$ \\
Complementary training for Advanced Life Support (N=131) & \\
Advanced Cardiac Life Support (ACLS) & $24(18.3)$ \\
Advanced Trauma Care for Nurses (ATCN) & $10(7.6)$ \\
Advanced Trauma Life Support (ATLS) & $4(3.0)$ \\
Basic Trauma Life Support (BTLS) & $3(2.2)$ \\
Pediatric Advanced Life Support (PALS) & $9(6.8)$ \\
Pre-hospital Trauma Life Support (PHTLS) & $26(19.8)$ \\
Trauma Life Support for Nurses (TLSN) & $5(3.8)$ \\
Training for Insertion of Peripherally Inserted Central Catheter & $8(6.1)$ \\
Training for Intraosseous Puncture & $21(16.0)$ \\
Training for Supraglottic Intubation - Laryngeal Mask & $20(15.2)$ \\
Did not complete any of these courses yet & $1(2.0)$ \\
\end{tabular}


Table 3 - Nurse responsibilities ( $n=50$ ), Florianópolis, Santa Catarina, Brazil, 2018

\begin{tabular}{|c|c|c|c|c|c|}
\hline Responsibilities & $\begin{array}{c}\mathbf{N} \\
\mathbf{n}(\%)\end{array}$ & $\begin{array}{c}\mathbf{R} \\
\mathbf{n}(\%)\end{array}$ & $\begin{array}{c}\text { AV } \\
n(\%)\end{array}$ & $\begin{array}{c}\mathbf{F} \\
\mathbf{n}(\%)\end{array}$ & $\begin{array}{c}\mathbf{S} \\
\mathbf{n}(\%)\end{array}$ \\
\hline \multicolumn{6}{|l|}{ PRE-FLIGHT } \\
\hline 1. Know the equipment and to perform maneuvers of manual extraction of victims & $2(4.0)$ & $3(6.0)$ & $9(18.0)$ & $13(26.0)$ & 23(46.0) \\
\hline 2. Estimate, requisition, and control materials and equipment used in the procedures & $1(2.0)$ & - & $3(6.0)$ & 16(32.0) & $30(60.0)$ \\
\hline 3. Prepare the aircraft with materials and equipment, according to the patient conditions & $1(2.0)$ & - & $2(4.0)$ & $7(14.0)$ & $40(80.0)$ \\
\hline 4. Install the equipment inside the aircraft & $1(2.0)$ & - & $3(6.0)$ & $12(24.0)$ & $34(68.0)$ \\
\hline 5. Check/test the functionality of each device & $1(2.0)$ & - & - & $7(14.0)$ & $42(84.0)$ \\
\hline $\begin{array}{l}\text { 6. Obtain information in the patient record and with the medical team about the patient's clinical } \\
\text { history; check for diseases or conditions that can affect the patient's clinical condition during the flight }\end{array}$ & $2(4.0)$ & $1(2.0)$ & $4(8.0)$ & $8(16.0)$ & $35(70.0)$ \\
\hline 7. Understand the expected flight time for proper service planning & $1(2.0)$ & - & $1(2.0)$ & $10(20.0)$ & $38(76.0)$ \\
\hline $\begin{array}{l}\text { 8. Perform with the physician the organization of the equipment, materials and medications, } \\
\text { establishing their disposition in the aircraft in order to offer a patient safe removal from the scene }\end{array}$ & $2(4.0)$ & $1(2.0)$ & $4(8.0)$ & $7(14.0)$ & $36(72.0)$ \\
\hline \multicolumn{6}{|l|}{ DURING FLIGHT } \\
\hline 9. Ensure nursing care integral for the patient, caring for their physical and mental integrity & $1(2.0)$ & - & - & $7(14.0)$ & $42(84.0)$ \\
\hline 10. Administer prescribed medications, or according institutional protocols & $1(2.0)$ & $1(2.0)$ & $4(8.0)$ & 14(28.0) & $30(60.0)$ \\
\hline 11. Evaluate and systematize the patient's priorities & $1(2.0)$ & $2(4.0)$ & $1(2.0)$ & 714.0) & $39(78.0)$ \\
\hline 12. Complete the nursing documentation in an objective, clear, and precise manner & 2(4.0) & $3(6.0)$ & - & $9(18.0)$ & $36(72.0)$ \\
\hline \multicolumn{6}{|l|}{ POS-FLIGHT } \\
\hline $\begin{array}{l}\text { 13. Refer the patient to the destination team, document in the patient records and provide all } \\
\text { information necessary for continuity of nursing care }\end{array}$ & $2(4.0)$ & $3(6.0)$ & $3(6.0)$ & $6(12.0)$ & $36(72.0)$ \\
\hline 14. Ensure the replacement of supplies and equipment used, according to institutional protocol & $1(2.0)$ & - & - & $7(14.0)$ & $42(84.0)$ \\
\hline $\begin{array}{l}\text { 15. Ensure the cleaning and disinfection of the aircraft interior where the patient was treated, and } \\
\text { equipment, according to institutional protocol }\end{array}$ & $2(4.0)$ & $2(4.0)$ & $3(6.0)$ & $12(24.0)$ & $31(62.0)$ \\
\hline 16. Report material expenses, medications, and possible intercurrences & $3(6.0)$ & $2(4.0)$ & $4(8.0)$ & $4(8.0)$ & $37(74.0)$ \\
\hline
\end{tabular}

Note: $N$ - NEVER; R-Rarely; S-Sometimes; O-Often; A - Always.

\section{DISCUSSION}

The characteristics of the nurses showed a predominance of male participation in the aerospace environment, contrary to the profile of Brazilian nursing, in which the female presence is dominant ${ }^{(10)}$. This result confirms the greater integration of men in nursing focuses on scenarios whose empirical understanding is the need for characteristics considered masculine, that is, that demand for physical strength, tenacity, and management of emotions ${ }^{(11-12)}$, such as: psychiatric emergency and emergency services ${ }^{(13)}$, intensive care units (ICUs) ${ }^{(14)}$, and mobile emergency care services ${ }^{(15-16)}$.

This area of nursing activity contributes to and, to a certain extent, reinforces the necessary gender debate in the profession. The deconstruction of preconceived ideas about femininity and masculinity in nursing enables the fragmentation of gender stereotypes, even allowing the end of inequalities in labor relationships ${ }^{(17)}$.

The sample consisted predominantly of nurses in the professional maturity stage, characterized by the full development of cognitive, technical, and practical abilities ${ }^{(10,15)}$. Regarding professional experience, the mean time of participants as nurses was ten years, with a six years mean of working in aircraft. Additionally, some of them had considerable accumulated professional experience. Similar results were described in a study on the profile of nurses from the mobile emergency care service of Santa Catarina, Brazil(15).
Regarding the region of actuation, $84 \%$ of the respondents were from the south, southeast, center-west, and federal district. This result may be associated with the concentration of nurses in these localities ${ }^{(10)}$. In addition, these regions are among the most urbanized in the country, which requires the state to provide and structure public policies to meet demands related to infrastructure, urban mobility, health, and public safety ${ }^{(18-19)}$. In this sense, advanced life support care, by means of aircraft, reduces the response time for care and transfer to referral hospitals in large urban centers ${ }^{(20)}$.

Regarding the type of institution and aircraft, the majority of nurses worked in public services (68\%), and in rotating wing aircraft (54\%). The numbers related to the first group can be explained by their linkage to public safety sectors in Brazil, such as the Brazilian Air Force (FAB), the Military Police, and the Fire Brigade ${ }^{(21)}$. Consequently, the use of airplanes is shared between public health and safety services, and is used not only for emergency services, but also in police operations, multimission, surveillance, and troop transport ${ }^{(18)}$. For these purposes, rotary-wing aircraft facilitate the movement and access to difficult-to-reach places, as they perform vertical landings without the need for a runway ${ }^{(21)}$.

Other data to be highlighted are that part of the nurses who are participants of this study started their activities without previous qualification. This finding can be considered alarming, considering the specificities of the work and the severity of the consultations performed in the aerospace environment. Lack 
of prior training was evidenced among nurses from the mobile emergency service in Santa Catarina, Brazil ${ }^{(15)}$, and health professionals from the air transportation of patients from a private company in Belo Horizonte, Brazil(22).

The nurses' weekly workload was approximately 36 hours, and an expressive part stated having another employment relationship. These results differ from studies in other work settings, in which the workload predominates, but with a unique professional link ${ }^{(14-15)}$. This finding can be related to the specificities of the work in the aerospace environment, in which the regime of work by shifts and on-call are common.

Monthly income is difficult to compare, because nursing does not have a minimum wage in Brazil. However, it is known that remuneration which conflicts with the working hours can lead to two or more employment positions and long working hours, which can negatively impact the health of the professional and, consequently, the quality of the care provided ${ }^{(14)}$.

The academic education focused on the "lato sensu" graduate degree in intensive care or urgent care/emergency. A small portion of the sample were specialists in aerospace nursing, which can be attributed to the fact that specialization courses in this area are still insufficient in Brazil, considering that this is a relatively new specialty. In addition, many nurses in this area have had previous experiences in other intensive care settings, which justifies specialization courses in these areas ${ }^{(3,8,23)}$.

In addition to the academic education, the search for complementary and specific courses to perform Advanced Life Support was identified, such as the Prehospital Trauma Life Support, which qualifies professionals for trauma care, and Advanced Cardiac Life Support, which aims at the development of basic and advanced life support skills for the treatment of acute cardiovascular events ${ }^{(23)}$. The search for these courses for professional improvement in the urgent care and emergency area was also identified in a survey of nurses from a private pre-hospital care service in the interior of Rio Grande do Sul, Brazil ${ }^{(3)}$. In addition, these courses are considered short-term and, for many, economically more affordable, compared to "lato sensu" graduate degree courses.

The interest in complementary education can also be associated with the need for specific knowledge according to the area of professional integration into the labor market after completion of the undergraduate degree. Thus, nursing care in the air service requires special formation and constant updating to attend to complex and unpredictable situations ${ }^{(3,14,23-24)}$.

In general, the result of this research show that nurses who practice in the aerospace environment contemplate what is provided by COFEN Resolution 0551/2017(9).

In the pre-flight stage, the most frequent activity by the participants was the verification and testing of the functionality of each device. Previous studies on the performance of the aeromedical service in Brazil $^{(1,3,8)}$ emphasize the importance of nurses in estimating and providing materials and equipment in the management of supplies in health services. The responsibility for testing the rescue bags, checking materials and supplies, and examination of equipment functionality should be shared with the onboard physician team, minimizing the possibility of errors, and increasing the safety for the patient ${ }^{(22,25)}$. Patient safety actions begin in aeromedical transport in the pre-flight phase, by means of proper planning of care in conjunction with the multidisciplinary team, and continues during the flight ${ }^{(26)}$.

During the flight, integral patient care was demonstrated as the main activity of the nurses. Nursing documentation, in an objective, clear, and precise manner, is a routine assignment performed by the participants of this study. The Resolution of COFEN no358/2009 reinforces the importance and the need of planning nursing care, and postulates that the implementation of the Systematization of Nursing Care (SAE) must occur in every public and private health institution. Even in the face of the specificities of the aerospace environment, the development of $\mathrm{SAE}$ is possible. It begins with pre-flight patient evaluation, care planning, and information on the clinical course of the patient during the removal and provision of data to the target institution ${ }^{(1,23)}$.

The activity performed with the least frequency during the flight was the administration of medications. This can indicate that most of the time the patient is stabilized on the ground, with no procedures required during the flight. In this sense, a study on emergency interventions in trauma victims of an aeromedical service demonstrated that the most frequent procedure was peripheral venous puncture for volume replacement or pre-flight medications $^{(27)}$.

In the post-flight, the main activity of the nurse was the replacement of supplies and equipment used, according to institutional protocol. This finding has also been identified in other studies on the subject, in which the disinfection, sterilization, and replacement of materials used, according to routines and documents of the institution, were presented as nursing activities in the post-flight stage $\mathrm{e}^{(26-27)}$. The administration characteristic of nurses is demonstrated in this care scenario, mainly regarding the management of materials, supplies, and equipment used during care.

In the post-flight period, the nurse is also responsible for the nursing care provided, documentation the patient's data in the patient record, and requesting the signature of the physician responsible for the patient in the hospital ${ }^{(23)}$.

The nurses' performance in pre-hospital mobile and interhospital services in aircraft, and the activities of service planning are shown as differentials for professional practice and execution of safer care during all the care performed.

\section{Limitations of the study}

The scarcity of information related to pre-hospital and interhospital services on aircraft in Brazil made it difficult to recruit participants from the institutions. In addition, while online data collection facilitates access to potential study participants, one cannot control who the respondent is. With regards to the origin of the respondents, the professional relationship of the researchers may have contributed to a higher rate of respondents from the Southern Region of Brazil.

\section{Contributions to the nursing area, health or public policy}

Although a regulation by COFEN regarding the nurses' activities in pre-hospital and inter-hospital care in air transport vehicles is already available, this study provides an overview of which activities are the most frequent, and can subsidize the preparation of future 
nurses interested in working in this area. Thus, the findings of the present study can contribute to the dissemination and expansion of aerospace nursing as a professional field in Brazil. As suggestions for further studies, it is necessary to investigate the nurses' working conditions in the aerospace environment, aiming for safe, quality care.

\section{CONCLUSIONS}

The workforce of nurses in the aerospace environment is mostly male, with adequate academic/complementary education to perform in critical care settings. Among the nurses' attributions, organizational and victim care actions were found during all stages of flight, resulting in comprehensive and safe care for the victims receiving treatment.

\section{FUNDING}

This study was financed in part by the Coordenação de Aperfeiçoamento de Pessoal de Nível Superior-Brasil (CAPES) - Finance Code 001.

\section{REFERENCES}

1. Scuissiato DR, Boffi LV, Rocha RR, Montezeli JH, Bordin MT, Peres AM. Flight nurses' comprehension about their role in the multiprofesional team of aero-medical transport. Rev. Bras. Enferm. 2012;65(4):614-20. doi: 10.1590/S0034-71672012000400010

2. Costa KS, Freitas GF, Hagopian EM. Men in nursing: academic education after graduation and professional trajectory. Rev Enferm UFPE[Internet]. 2017[cited 2019 Mar 21];11(3):1216-26. Available from: https://periodicos.ufpe.br/revistas/revistaenfermagem/article/ view/13497/0

3. Bonuzzi KL, Muniz-Silva CCS, Santos OP, Moraes-Filho IM, Lopes VC, Silva RM. Nurses' performance in air pre-hospital care for polytraumatized patients: review of literature. Rev Cient Sena Aires. [Internet]. 2016[cited 2019 Mar 21];5(2):171-77. Available from: http:// revistafacesa.senaaires.com.br/index.php/revisa/article/view/268/147

4. Faria TLM, Nascimento DB, Farias Filho MC, Nunes SF. [National Policy of Urgency and Emergency under the Federal Coordination in Pará Municipalities, Brazil]. Saude Soc [Internet]. 2017[cited 2019 Mar 21];26(3):726-37. Available from: https://www.scielo.br/pdf/sausoc/ v26n3/0104-1290-sausoc-26-03-00726.pdf Portuguese

5. Kaniecki DM. Response of Flight Nurses in a Simulated Helicopter Environment. Air Med J. [Internet]. 2017[cited 2019 Mar 21];36(3):131-4. Available from: https://www.ncbi.nlm.nih.gov/pubmed/28499683

6. Boyd LR, Borawski J, Lairet J, Limkakeng AT Jr. Critical Care Air Transport Team severe traumatic brain injury short-term outcomes during flight for Operation Iraqi Freedom/Operation Enduring Freedom. J R Army Med Corps. 2017;163(5):342-6. doi: 10.1136/jramc-2016-000743

7. Brideson G, Willis E, Mayner L, Chamberlain DJ. Images of flight nursing in Australia: A study using institutional ethnography. Nurs Health Sci. 2016;18(1):38-43. doi: 10.1111/nhs.12225

8. Costa NM, Mello RZR, Oliveira TCM, Parreiras MM, Silva RR, Silva KR. [The entrepreneurial perspective of nurses: training and actuation of professionals in aeromedical transportation.]. Per Científ Núc Biociências[Internet]. 2013[cited 2019 Mar 21];3(5):39-49 Available from: w3.izabelahendrix.edu.br/ojs/index.php/bio/article/view/449. Portuguese

9. Conselho Federal de Enfermagem. Resolução n0551, de julho de 2017. Normatiza a atuação do Enfermeiro no atendimento Pré-Hospitalar Móvel e Inter-Hospitalar em Veículo Aéreo. 2017.

10. Machado MH. [General Characteristics of Nursing: the sociodemographic profile]. Enferm. Foco [Internet]. 2015[cited 2019 Mar 21];6(1):117. Available from: http://revista.portalcofen.gov.br/index.php/enfermagem/article/download/686/296. Portuguese

11. Santos RM, Barros LMC, Santos SA, Santos WB, Costa, LMC. [Male insertion in nursing: what is writing on this question?]. Rev Cult Cuidados[Internet]. 2017[cited 2019 Mar 21];48:219-32. Available from: https://rua.ua.es/dspace/bitstream/10045/69278/1/CultCuid_48_24. pdf. Spanish

12. Cottingham MD. Caring moments and their men: masculine emotion practice in nursing. NORMA: Int J Masculin Stud [Internet]. 2017[cited 2019 Mar 21];12(3):270-85. Available from: https://www.tandfonline.com/doi/full/10.1080/18902138.2017.1312954

13. Vargas D, Soares J, Ponce TD, Oliveira BB. Psychiatric urgency and emergency care nurses: an analysis of their professional and educational profile. Cogitare Enferm [Internet]. 2017[cited 2019 Mar 21];22(4). Available from: http://www.saude.ufpr.br/portal/revistacogitare/wpcontent/uploads/sites/28/2017/10/50704-219743-1-PB.pdf

14. Viana, RAPP, Vargas MAO, Carmagnani MIS, Tanaka LH, Luz KR, Schmitt PH. Profile of an intensive care nurse in different regions of Brazil. Texto Contexto Enferm[Internet]. 2014 [cited 2019 Mar 21];23(1):151-9. Available from: http://www.scielo.br/pdf/tce/v23n1/pt_0104-0707tce-23-01-00151.pdf

15. Luchtemberg MN, Pires DE. Nurses from the Mobile Emergency Service: profile and developed activities. Rev Bras Enferm[Internet]. 2016[cited 2019 Mar 21];69(2):213-20. Available from: http://www.scielo.br/pdf/reben/v69n2/en_0034-7167-reben-69-02-0213.pdf

16. Garçon TL, Pupulim MJS. Quality of emergency in mobile prehospital care in the perspective of professionals. Cienc Cuid Saúde [Internet]. 2017[cited 2019 Mar 21];16(4):8. Available from: http://periodicos.uem.br/ojs/index.php/CiencCuidSaude/article/view/37306/21749

17. Galbany-Estragués P, Comas-d'Argemir D. Care, autonomy, and gender in nursing practice: a historical study of nurses' experiences. J Nurs Res. 2017;25(5):361-7. doi: 10.1097/JNR.00000000000000184 
18. Fonseca SO. [Specialized aeromedical service - a new vision in rescue and aeromedical transport for Santa Catarina.] Ignis: revista técnico científica do Corpo de Bombeiros Militar de Santa Catarina. [Internet]. 2017[cited 2019 Mar 21];2(1):152-71. Available from: https:// biblioteca.cbm.sc.gov.br/biblioteca/index.php/component/docman/doc_download/627-sandro-fonseca Portuguese

19. Instituto Brasileiro de Geografia e Estatística-IBGE [Internet]. 2018[cited 2019 Mar 21]. Available from: http://www.ibge.gov.br/home/

20. Chen X, Gestring ML, Rosengart MR, Billiar TR, Peitzman AB, Sperry JL, Brown JB.Speed is not everything: Identifying patients who may benefit from helicopter transport despite faster ground transport. J Trauma Acute Care Surg.. 2018;84(4):549-57. doi: 10.1097/ TA.0000000000001769

21. Gomes MAV, Alberti LR, Ferreira FL, Gomes VM. Historical aspects of aeromedical transport and aerospace medicine - review. Rev. Med. Minas Gerais. [Internet]. 2013[cited 2019 Mar 21];23(1):116-23. Available from: http://rmmg.org/exportar-pdf/20/en_v23n1a18.pdf

22. Dias CP, Penna CMM. Air transport: the daily lives of health professionals. Rev Enferm UFPE[Internet]. 2014[cited 2019 Mar 21];8(2):3600-06. Available from: https://periodicos.ufpe.br/revistas/revistaenfermagem/article/viewFile/10099/10562

23. Schweitzer G, Nascimento ERP, Nascimento KC, Moreira AR, Amante LN, Malfussi LBH. Emergency interventions for air medical services trauma victims. Rev Bras Enferm. 2017;70(1):54-60. doi: 10.1590/0034-7167-2016-0311

24. Nascimento KC, Fernandes CF, Girondi JBR, Sebold LF, Hammerschmidt KSA, Moreira AR. Elderly people receiving care through an aeromedical service. Rev. Bras. Geriatr. Gerontol [Internet]. 2018[cited 2019 Mar 21]21(1):82-90. Available from: http://www.scielo.br/pdf/ rbgg/v21n1/pt_1809-9823-rbgg-21-01-00079.pdf

25. Azevedo LSL, Ribeiro LG, Schmidt A, Pazin FA. Impact of training in Advanced Cardiac Life Support (ACLS) in the professional career and work environment. Ciênc Saúde Coletiva[Internet]. 2018[cited 2019 Mar 21];23(3):883-90. Available from: http://www.scielo.br/pdf/csc/ v23n3/1413-8123-csc-23-03-0883.pdf

26. Santos HGL, Guedes CCP, Aguiar BGC. [Patient safety in air medical transport: a reflection on the work of nurses] Rev Acred [Internet]. 2014[cited 2019 Mar 21];4(7):21-34 Available from: https://dialnet.unirioja.es/descarga/articulo/5626590.pdf. Portuguese

27. Schweitzer G, Nascimento E.R.P, Moreira A.R, Bertoncello K.C.G. [Protocol of nursing care to traumatized patients in the aerospace environment: care before flight]. Rev Bras Enferm[Internet]. 2011 [cited 2019 Mar 21];64(6):1056-66. Available from: http://www.scielo.br/ pdf/reben/v64n6/v64n6a11.pdf. Portuguese 